\title{
Vocabulary Journaling To Improve Reading Comprehension
}

\author{
Ms. Eunice Lai Quan Nin \\ Sri Bestari International School, \\ Bandar Sri Damansara, Malaysia \\ Professor Dr. Mogana Dhamotharan \\ Faculty of Education, SEGi University, \\ Kota Damansara, Malaysia
}

\begin{abstract}
Although the importance of vocabulary in language input (listening and reading) and output (speaking and writing) has long been established, time constraints and examoriented instruction in the Malaysian secondary school classrooms force teachers to prioritize content breadth rather than depth. In 2017, the Malaysian Ministry of Education implemented nationwide the new Standard Based Curriculum for Secondary Schools (KSSM). The integration of the Vocabulary Journal in the new textbook demonstrates the importance of vocabulary in language learning. This paper aims to present and share the findings of an action research study with a selected class of Form One students (13 year olds) engaged in vocabulary journaling to determine its effectiveness in enhancing vocabulary knowledge as well as reading comprehension. Vocabulary journals are also known as personalised dictionaries for learners of English as a Second Language (ESL) which allows them the freedom to include any information they deem relevant to the target words. To ease the process of deciding which information to be included, the vocabulary journaling used Frayer's (1969) Vocabulary Four Square Model. This paper will share the findings from the study on enlisting the vocabulary journal approach to enhance the learners' vocabulary range, thereby leading to improved reading comprehension.
\end{abstract}

Keywords: Vocabulary journal, Vocabulary, Reading comprehension, Secondary school ESL learners

\section{INTRODUCTION}

Malaysian students are especially fortunate as they are exposed to multiple languages on a daily basis since the country consists of a multiracial population. Though students may have different mother tongues, English is a core subject that each student has to take up beginning from their early education years and it eventually becomes the medium of instruction as learners progress through their education. Therefore, 11 crucial years have been allocated in the Malaysian education system to train learners in the lingua franca. However, studies have shown that despite the 11 years of compulsory English language education received, Malaysian ESL learners still lack the necessary proficiency levels for higher levels of language use. Researchers claim that this lack of proficiency can be traced to the lack of extensive reading, limiting their vocabulary depth and breadth and increasing their heavy reliance on translation into their L1 (Hazlina Abdullah, Nik Suryani Nik Abdul Rahman \& Airil Haimi Mohd. Adnan, 2012).

Acknowledging the importance of the English language and the loopholes of the previous curriculum, the Ministry of Education Malaysia has introduced the Standards-Based English Language Curriculum (SBELC) to improve English proficiency levels of the youths starting from 
their first year in primary education (Tajularipin Sulaiman, Ahmad Fauzi Mohd Ayub \& Suriati Sulaiman, 2015). Beginning with the first batch in 2011, students who have undergone six years of the Primary School Standards-Based Curriculum, otherwise known as the Kurikulum Standard Sekolah Rendah (KSSR) are now the first cohort of students undergoing the new Standard Based Curriculum for Secondary Schools, also known as the Kurikulum Standard Sekolah Menengah (KSSM). Under the new curriculum, a vocabulary journal component has been added into the textbook to help learners expand their vocabulary breadth and depth which the researcher believes to be the root of the poor language proficiency levels. Aside from the emphasis on the four basic language skills: reading, listening, speaking and writing, the SBELC entrusts teachers with the responsibility of assisting the students develop higher order thinking skills such as reasoning, critical thinking and creative thinking skills that are crucial in communication (Curriculum Development Division, 2011).

It is no surprise to find that teachers too are resistant toward the restructuring of the curriculum as it may entail an increase to their already overburdening workload, while also raising their insecurities about being incompetent in implementing the restructured curriculum with the limited amount of training and support that they receive (Tajularipin Sulaiman, Ahmad Fauzi Mohd Ayub \& Suriati Sulaiman, 2015). The teachers' concerns are legitimate as they are forced to adapt to not only the restructured curriculum, but also to their new teaching roles, new content and materials as well as the philosophy that comes with the restructuring of the curriculum simultaneously (Tajularipin Sulaiman, Ahmad Fauzi Mohd Ayub \& Suriati Sulaiman, 2015). As the researcher happened to be presented with the opportunity to conduct her teaching practice when the curriculum was implemented, it was a great opportunity to identify whether the incorporation of the vocabulary journal component in the English textbook was indeed effective in helping learners improve their vocabulary range, which would then increase their reading comprehension gains.

The study was guided by the following research questions:

1. How does explicit vocabulary instruction help the selected class of Form One students to gain more vocabulary?

2. How does explicit vocabulary instruction help the selected class of Form One students to improve reading comprehension?

3. To what extent does the vocabulary journal method help the selected class of Form One students gain more vocabulary and improve reading comprehension?

Past research has indicated that one of the possible reasons behind the lack of language proficiency levels among the learners can be traced to the learners themselves who are unaware of effective word learning strategies, causing them to be unable to comprehend language input in the form of reading texts as well as verbal exchanges as they struggle to understand the words used.

\section{Vocabulary Learning Strategies}

It is widely acknowledged that vocabulary plays a crucial role in enabling learners to effectively express themselves for communicative purposes (Glende, 2013; Vela \& Rushidi 2016; Centenario, 2013; Rupley \& Nichols, 2005). Despite teachers' best interests, it is a herculean task to expect teachers to be able to teach every single word that students encounter for the obvious reason that words are multi-faceted and are constantly fluctuating in numbers (Nagy, 1988), and teachers in schools are pressured by time constraints due to the emphasis placed on examinations (Hazlina Abdullah, Nik Suryani Nik Abdul Rahman \& Airil Haimi Mohd. Adnan, 2012). To further illustrate the severity of this problem, some researchers term the dual task of mastering both content and language simultaneously as the double-edged sword 
that significantly impacts English language learning for ESL learners (Boyer, 2017; Farrukh Nazir, 2017; Robson, 2009; Townsend \& Collins, 2008)

Therefore, researchers assert that it would be far more effective for teachers to equip learners with vocabulary learning strategies instead of merely expecting learners to pick up these strategies as they progress in their learning (Azadeh Asgari \& Ghazali Bin Mustapha, 2011; Nagy, 1988; Zhang and Suaini bin Anual, 2008; Naginder, 2013; Farrukh Nazir, 2017). Researchers such as Beck, Perfetti \& McKeown (1982), Glende (2013), Naginder (2013), Nelson \& Stage (2007), Rupley \& Nichols (2005) Yung (2008) suggest that teachers help learners by equipping them with vocabulary learning strategies instead of focusing on teaching them words, as this allows them to become autonomous learners enabling them to cope with the progressively increasing demands in their learning. Schmitt's Taxonomy (1997) aptly sums up some of the more common strategies used by learners to acquire and expand their vocabulary ranges though the learners may not be fully aware of them.

\section{Schmitt's Taxonomy of Vocabulary Learning Strategies}

There are a myriad of vocabulary learning strategies available and it is difficult to pinpoint one that would guarantee results for all learners. Therefore, researchers have documented and classified the myriad of vocabulary learning strategies available into various taxonomies. The current study refers to Schmitt's (1997) taxonomy of vocabulary learning strategies (Figure 1), as it seems to be the most comprehensive and has been selected as the basis of the current study (Azadeh Asgari \& Ghazali Bin Mustapha, 2011).

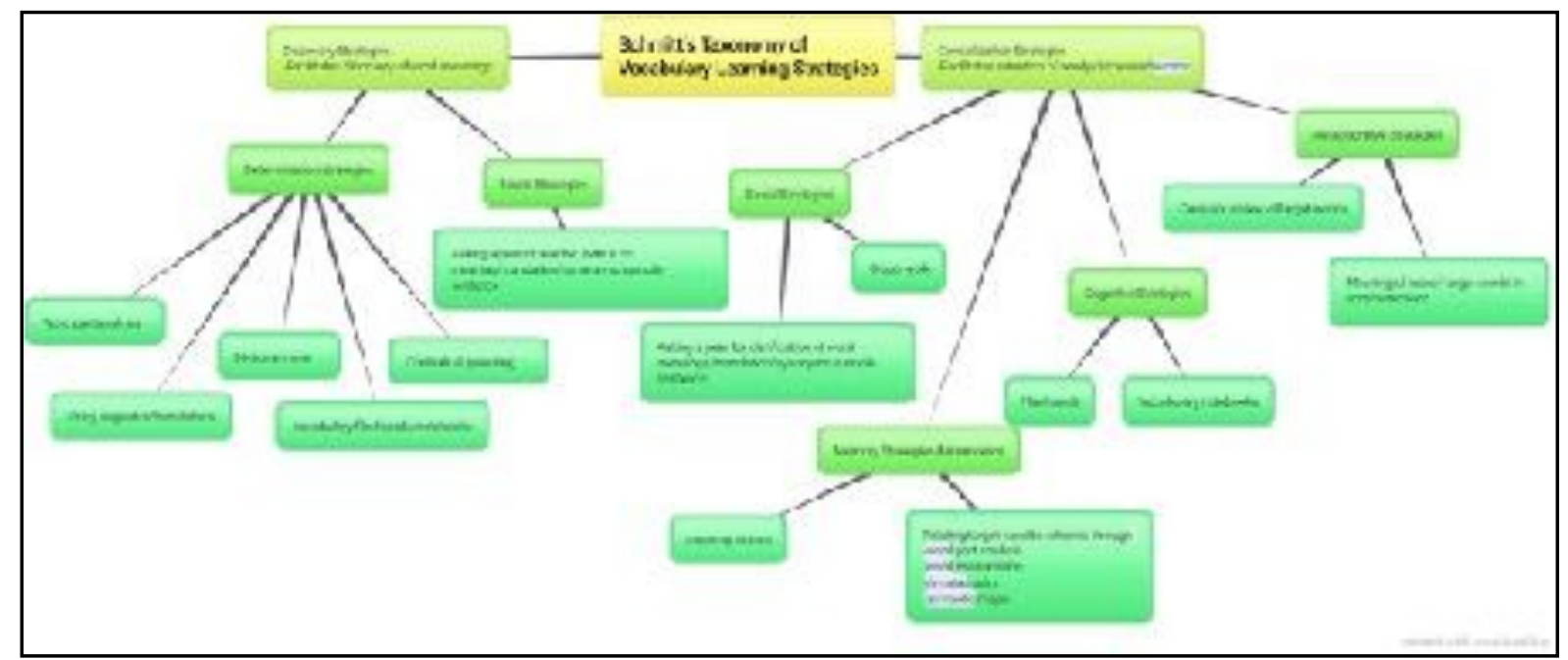

Figure 1. Schmitt's (1997) Taxonomy of Vocabulary Learning Strategies

Based on Schmitt's (1997) taxonomy (Figure 1), vocabulary learning strategies are classified into two broad categories: Discovery strategies and consolidation strategies, which are then broken down further into specific clusters of strategies such as determination, social, metacognitive and cognitive strategies respectively. Though the taxonomy presents an array of strategies at the disposal of the learners as well as teachers, research has indicated that not many were aware of its presence and hence were unable to reap its benefits (Azadeh Asgari \& Ghazali Bin Mustapha, 2011; Dubiner, 2017; Rupley \& Nichols, 2005; Taveggia, 2013; Uzun, 2012).

Ideally, teachers would be able to model as many of these learning strategies for their learners as possible, but it is not a practical goal to achieve due to the limited instructional time (Centenario, 2013; Townsend \& Collins, 2008), pressure of the exam-oriented education system in the Malaysian context (Hazlina Abdullah, Nik Suryani Nik Abdul Rahman \& Airil 
Haimi Mohd. Adnan, 2012), as well as the passive attitudes of the learners (Darmi \& Albion, 2013; Hazlina Abdullah, Nik Suryani Nik Abdul Rahman \& Airil Haimi Mohd. Adnan, 2012; Loshuertos Centenario, 2013; Zhang \& Suaini Bin Anual, 2008). Therefore, teachers and researchers alike are in search of the most effective and practical way to help learners, especially ESL learners in the Malaysian context master a larger vocabulary range to help them in their language learning.

Based on Figure 1, it can be seen that keeping a vocabulary notebook involves the use of multiple discovery and consolidation strategies in the process (Mania Nosratinia, Zania Mohamadi Sarmadi \& Hossein Shakeri, 2013). In line with the Involvement Load Hypothesis by Hulstijn and Laufer (2001), keeping a vocabulary notebook requires the learners to engage in multiple vocabulary learning strategies, which translates to a higher involvement load and subsequently higher retention of target words learned (Hulstijn and Laufer, 2001). Also agreeing with Hulstijn and Laufer (2001) is Yung (2008, p. 71), a researcher in Hong Kong who states that "vocabulary notebooks can be used as a tool to integrate a variety of learning strategies and make them explicit to students." Studies conducted by Boyer (2017), Chou (2011), Dubiner (2017), Glende (2013), Mahdavi \& Tensfeldt (2013), Shen (2013) and Sippel (2010) also support the notion that a combination of vocabulary learning strategies proved to be more effective in helping learners acquire and retain vocabulary necessary for successful reading comprehension compared to the isolated use of a particular strategy. Therefore, it indicates that the use of a vocabulary notebook is indeed an effective method to help ESL learners in their language learning.

\section{Vocabulary Notebooks}

Though vocabulary journaling is a new component integrated in the Malaysian English language curriculum, this vocabulary learning strategy has long been employed in language classrooms in other countries. Uzun $(2012$, p.2) states that: "since vocabulary notebooks provide learners with the opportunity to expand their repertoire of vocabulary, help them enhance vocabulary learning strategies, and encourage individual learning, the effectiveness of vocabulary notebooks should be investigated more closely". This is further supported by Yung (2008, p.71) who claims that, "vocabulary notebooks can be used as a tool to integrate a variety of learning strategies and make them explicit to students".

Past studies on vocabulary notebooks have presented positive findings such as:

- Increased vocabulary acquisition and retention (Dubiner, 2017; Centenario, 2013; McCrostie, 2007; Uzun, 2012, Yung, 2008).

- Development of language learning strategies (Dubiner, 2017; Loshuertos Centenario, 2013; McCrostie, 2007; Vela \& Rushidi, 2016).

- Increased learner motivation and autonomy (Dubiner, 2017; Centenario, 2013; McCrostie, 2007; Taveggia, 2013; Uzun, 2012; Vela \& Rushidi, 2016; Walters and Bozkurt, 2009; Yung, 2008).

- Increased reading comprehension (Yung, 2008).

Aside from being a combination of multiple vocabulary learning strategies (Mania Nosratinia, Zania Mohamadi Sarmadi \& Hossein Shakeri, 2013; Dubiner, 2017; Centenario, 2013; Schütz, 2005) are of the opinion that the use of a vocabulary notebook is also a practical and effective approach as it is economical and allows adolescent students who desire independence and determination the freedom to design their notebooks and include any information they deem important. Perhaps acknowledging these benefits, the Ministry of Education Malaysia has integrated the 'Vocabulary Journal' component in the new Kurikulum Standard Sekolah Menengah (KSSM) syllabus English textbook. 
Though vocabulary notebooks seem to be a promising strategy to help ESL learners with their language learning, past studies have presented potential areas for improvement as follows:

1) Vocabulary learning should take place in a communicative environment that allows learners to develop expressive language skills such as through discussions and games (Chung, 2012; Farrukh Nazir, 2017; Fisher \& Frey, 2014; Uzun, 2012).

2) Vocabulary notebooks should be included in the formative assessment of the learners to encourage learners to consistently add entries into their notebooks (Dubiner, 2017; Walters \& Bozkurt, 2009; Vela \& Rushidi, 2016).

3) Teachers should periodically review the notebooks and correct errors made in the notebooks to allow learners to notice their mistakes instead of constantly relying on sample sentences to learn the multidimensionality of the words (Dubiner, 2017; Centenario, 2013; McCrostie, 2007; Walters \& Bozkurt, 2009; Uzun, 2012; Yung, 2008).

4) Teachers should scaffold their vocabulary learning by modelling different strategies in the classroom instead of spoon-feeding the learners with information to prepare them to be able to handle questions that require learners to infer meanings of unknown words (Centenario, 2013; Yung, 2008; Zhang \& Suaini Bin Anual, 2008).

5) Though learners should be given the freedom to select the words to include in their notebooks, teacher guidance is necessary. Thus, teachers should provide a word list for learners to refer to, consisting of about 10-20 words over the span of a week (McCrostie, 2007; Taveggia, 2013; Vela \& Rushidi, 2016; Walters \& Bozkurt, 2009; Yung, 2008).

6) Though learners should be given the freedom to select the words to include in their notebooks, teacher guidance is necessary. Thus, teachers should provide a word list for learners to refer to, consisting of about 10-20 words over the span of a week (McCrostie, 2007; Taveggia, 2013; Vela \& Rushidi, 2016; Walters \& Bozkurt, 2009; Yung, 2008).

7) Although vocabulary notebook entries typically only include definitions, sample sentences and related words, other information such as collocations and visuals should be included to promote in-depth understanding of the target words learned (Boyer, 2017; Mania Nosratinia, Zania Mohamadi Sarmadi \& Hossein Shakeri, 2013; McCrostie, 2007; Taveggia, 2013; Yung, 2008).

Though it is important to allow learners the freedom to include any additional information about the target words they deem relevant, multiple studies have found that learners also need assistance in selecting the type of additional information that helps enhance their understanding of the target words chosen (Boyer, 2017; Mania Nosratinia, Zania Mohamadi Sarmadi \& Hossein Shakeri, 2013; Taveggia, 2013; Yung, 2008).

The study employed the use of the Frayer's Vocabulary Four Square Model as results from Peters' (1975) study have indicated that this was a far more effective method in helping struggling learners attain concepts in reading material. The results indicated that attainment of concepts lead to improved reading comprehension performance among the participants (Peters, 1975). Therefore, the vocabulary journal in this study was guided by Frayer's Vocabulary Four Square Model as the template for participants' vocabulary journal entries, while Marzano's Six Steps to Better Vocabulary Instruction (2009) laid the foundation for the implementation of the study with the participants.

\section{METHODOLOGY}

The study aimed at identifying whether the use of a vocabulary journal was indeed effective in helping learners in the Malaysian secondary school setting gain more vocabulary and improve their reading comprehension abilities. More specifically, the study aimed at identifying 
whether the use of a vocabulary journal guided by Frayer's Vocabulary Four Square Model was effective in helping learners acquire more vocabulary as well as improve their reading comprehension. To further substantiate the findings, the participants' input was also taken into account in the study. The study was therefore guided by the following research questions:

1. How does explicit vocabulary instruction help the selected class of Form One students to gain more vocabulary?

2. How does explicit vocabulary instruction help the selected class of Form One students to improve reading comprehension?

3. To what extent does the vocabulary journal method help the selected class of

Form One students gain more vocabulary and improve reading comprehension?

\section{PARTICIPANTS}

The 34 participants were purposefully selected from an intact class of Form One students in a selected school in Petaling Utama, Malaysia as they were the first batch of students to undergo the Standard Based Curriculum for Secondary Schools (KSSM) syllabus. Purposive sampling allowed for collection of a more comprehensible set of data for a better understanding of the effects of the use of a vocabulary journal on the vocabulary and reading comprehension gains on these ESL learners (Creswell, 2012).

It is important to note that these participants mainly come from non-English speaking backgrounds and have achieved at least a B grade in their Primary School Achievement Test, also known as Ujian Pencapaian Sekolah Rendah (UPSR) examination for their comprehension paper. This indicated that they had acquired at least some form of proficiency in the language, at least according to the examination results.

\section{Instruments}

Data for the study were collected using the following instruments: a) Vocabulary Knowledge Scale (VKS) Pre-tests and Post-tests, b) Reading Comprehension Pre-test and Post-test, c) Written response questions, and d) Frayer's Vocabulary Four Square Model.

\section{Vocabulary Knowledge Scale (VKS) Pre-tests and Post-tests}

The Vocabulary Knowledge Scale (VKS) is a 5-point self-report scale developed by Wesche \& Paribakht (1996) to help educators track the vocabulary acquisition progress of L2 learners by including receptive and productive measures of vocabulary knowledge. The VKS used in the this study was modified by Dale Brown (2011) of Nanzan University in Japan, consisting of a 4point self-report Likert scale, supplying evidence for the vocabulary gains that have been claimed by Stahl and Nagy (2006) as incremental in learners of all proficiency levels (as cited in Townsend and Collins, 2008, p.1012). Furthermore, according to Brown (2011, p.15), this form of measurement allowed for a "finer measurement of vocabulary gains" as it allowed students to self-report their "progressive degrees of word knowledge", while also requiring them to supply evidence of their understanding. The following is the scoring guide for the VKS used in this study:

- $A=I$ know the meaning of this word/phrase and can use it in a sentence. ( 3 points)

- $\mathrm{B}=\mathrm{I}$ know the meaning of this word/phrase but I am not sure how to use it. (2 points)

- $\mathrm{C}=\mathrm{I}$ have seen this word/phrase before, but I do not know what it means. (1 point)

- $\mathrm{D}=\mathrm{I}$ have never seen this word/phrase before. (0 points)

The study managed to gather three cycles of data in the form of VKS, with 10-15 chosen words from each topic covered in the lessons. 


\section{Reading Comprehension Pre-test and Post-test}

Since the participants were being prepared to sit for the Form Three Assessment (Penilaian Tingkatan Tiga) examinations in the near future, the reading comprehension test was extracted from the 2016 (PT 3) examination. Only the Section C component of the (PT 3) paper was used as it consisted of open-ended comprehension questions that required learners to demonstrate breadth and depth of vocabulary, allowing for more valid data to be collected to support the findings.

\section{Written Response Questions}

The written response session was conducted upon completion of the intervention, offering insights from the participants themselves on the effectiveness of the vocabulary journal. The questions used in the handout were adapted from the questionnaire used in Yung's (2008) study with his class of Form 2 ESL learners in Hong Kong. A total of eight open-ended questions were given to the students in the form of individual handouts.

\section{PROCEDURE FOR DATA COLLECTION}

Before the intervention was introduced, the participants were subjected to the first Vocabulary Knowledge Scale pre-test and the reading comprehension pre-test. Then, the vocabulary journal was introduced in the classroom and modelled how the Frayer's Vocabulary Four Square Model could be used as the template for the participants' vocabulary journal entries. The word list for each topic, consisting of 10-15 words per topic was posted in the classroom at the beginning of the topic, allowing participants the time to complete their vocabulary journals at home before sharing their entries with the class in the next lesson. Wherever possible, the researcher included some enrichment games such as Hangman and verbal pop quizzes to help the participants recall the target words. At the end of each topic, the vocabulary journals were collected for checking before the post-test was administered. Feedback was given each time the participants shared their entries with the class and after the post-test.

Each topic took approximately 3 weeks to cover, and at the end of every 3 weeks, the participants would be subjected to a Vocabulary Knowledge Scale post-test. At the end of the intervention, the participants had to do the reading comprehension post-test.

Two weeks later, the written response session was conducted, but not all participants were present for the session. Only 25 of the 30 participants managed to present themselves for the written response session.

Only 30 participants participated fully in the study as 4 of the participants were either transferred to a different school in the middle of the intervention period or experienced physical injury, causing them to be absent from school during the intervention period.

\section{FINDINGS AND DISCUSSION}

\section{Results from the Vocabulary Knowledge Scale (VKS) Pre-tests and Post-tests}

Three cycles of the Vocabulary Knowledge Scale (VKS) were conducted and the results are presented in Table 1. The scores shown are for 30 participants who had participated fully in the study. 
Table 1:

Pre-test and Post-test mean scores for all three cycles of Vocabulary Knowledge Scale (VKS)

Vocabulary Knowledge Pre-test Mean Score Post-test Mean Score

Scale Cycle

\begin{tabular}{lll}
\hline Cycle 1 (15 words) & 20.50 & 22.90 \\
\hline Cycle 2 (10 words) & 17.03 & 22.97 \\
\hline Cycle 3 (10 words) & 10.03 & 17.03 \\
\hline
\end{tabular}

*Total score for Cycle $1=45$ points

*Total scores for Cycle 2 and $3=30$ points

The decrease in the number of target words chosen was due to the lack of time which was noticed on completing the First Cycle. Based on the consistent increase in post-test scores from the pre-test scores for all three Cycles of the Vocabulary Knowledge Scale pre and post- tests, it was clear that the use of a vocabulary journal helped the participants acquire more vocabulary knowledge depth. This sufficiently answered the first research question, showing that the vocabulary journal was indeed effective in helping the participants gain depth of vocabulary incrementally through multiple exposures to the definition, sample sentences, visuals and associated words of the target words chosen.

These findings were consistent with those of previous studies that had engaged the use of vocabulary notebooks and explicit vocabulary instruction to help learners increase vocabulary breadth and depth (Apthorp et al., 2012; Azadeh Asgari \& Ghazali Bin Mustapha, 2011; Chung, 2012; Dubiner, 2007; Kusumawati \& Widiati, 2017; Farrukh Nazir, 2017; Langenberg, 2000; Loshuertos Centenario, 2013; Nelson \& Stage, 2007; Mania Nosratinia, Zania Mohamadi Sarmadi \& Hossein Shakeri, 2013; McCrostie, 2007; Ortlieb, Verlaan, \& Cheek, 2013; Robson, 2009; Rupley \& Nichols, 2005; Taveggia, 2013; Townsend \& Collins, 2008; Uzun, 2012; Vela \& Rushidi, 2016; Yung, 2008).

\section{Results from the Reading Comprehension Pre-test and Post-test}

The pre-test and post-test results for the reading comprehension test serve as an indicator of the effectiveness of the intervention method and the results are shown in Table 2.

Table 2:

Mean Scores for Reading Comprehension Pre-test and Post-test

\begin{tabular}{lll}
\hline Reading Comprehension & Pre-test & Post-test \\
\hline Mean Scores & 8.33 & 10.10 \\
\hline
\end{tabular}

*Total score: 15 marks

The results in Table 2 clearly show that the participants were able to score significantly better in the post-test as compared to the pre-test. The increase indicated that the participants did indeed benefit from the vocabulary journaling exercise, which translated to gains in their reading comprehension performances. It is important to note that none of the words used in the reading comprehension tasks was included in any of the vocabulary journaling exercises throughout the intervention period.

These findings confirmed the findings of other studies that had attempted to identify a positive correlation between using explicit vocabulary instruction to assist reading comprehension (Azadeh Asgari \& Ghazali Bin Mustapha, 2011; Beck, Perfetti \& McKeown, 1982; Boyer, 2017; 
Chou, 2011; Glende, 2013; Chung, 2012; Cuevas, Russell \& Irving, 2012; Kusumawati \& Widiati, 2017; Langenberg, 2000; McCrostie, 2007; Nelson \& Stage, 2007; Robson, 2009; Rupley \& Nichols, 2005; Shen, 2013; Wang, 2013; Zhang \& Suaini Bin Anual, 2008).

\section{Results from the Written Response Session}

Data to answer the last research question were collected using the eight open-ended questions adapted from Yung's (2008) study with his Form 2 Chinese as a Medium of Instruction (CMI) class of ESL learners in Hong Kong. Only 25 participated in this session as it was conducted on the last day of the academic semester and not all of them were present.

The eight questions used in the written response session were adapted from the findings discussed in five themes as follows:

Theme 1: Participants' preferred language of communication.

Theme 2: Participants' perceived difficulty of English reading comprehension questions and preferred answering methods.

Theme 3: Previous vocabulary learning strategies and effectiveness.

Theme 4: Response to the use of a vocabulary journal and its effectiveness.

Theme 5: Intention to continue using the vocabulary journal.

\section{Theme 1: Participants' Preferred Language ofCommunication}

The first question was concerned with the first language of the participants, since ESL learners are constantly claimed to lack exposure to literacy events and opportunity to interact with quality text, which consequently leads to learners lacking in background knowledge required for successful reading comprehension to occur (Glende, 2013; Rupley \& Nichols, 2005). The results are shown in Figure 2 beloww.

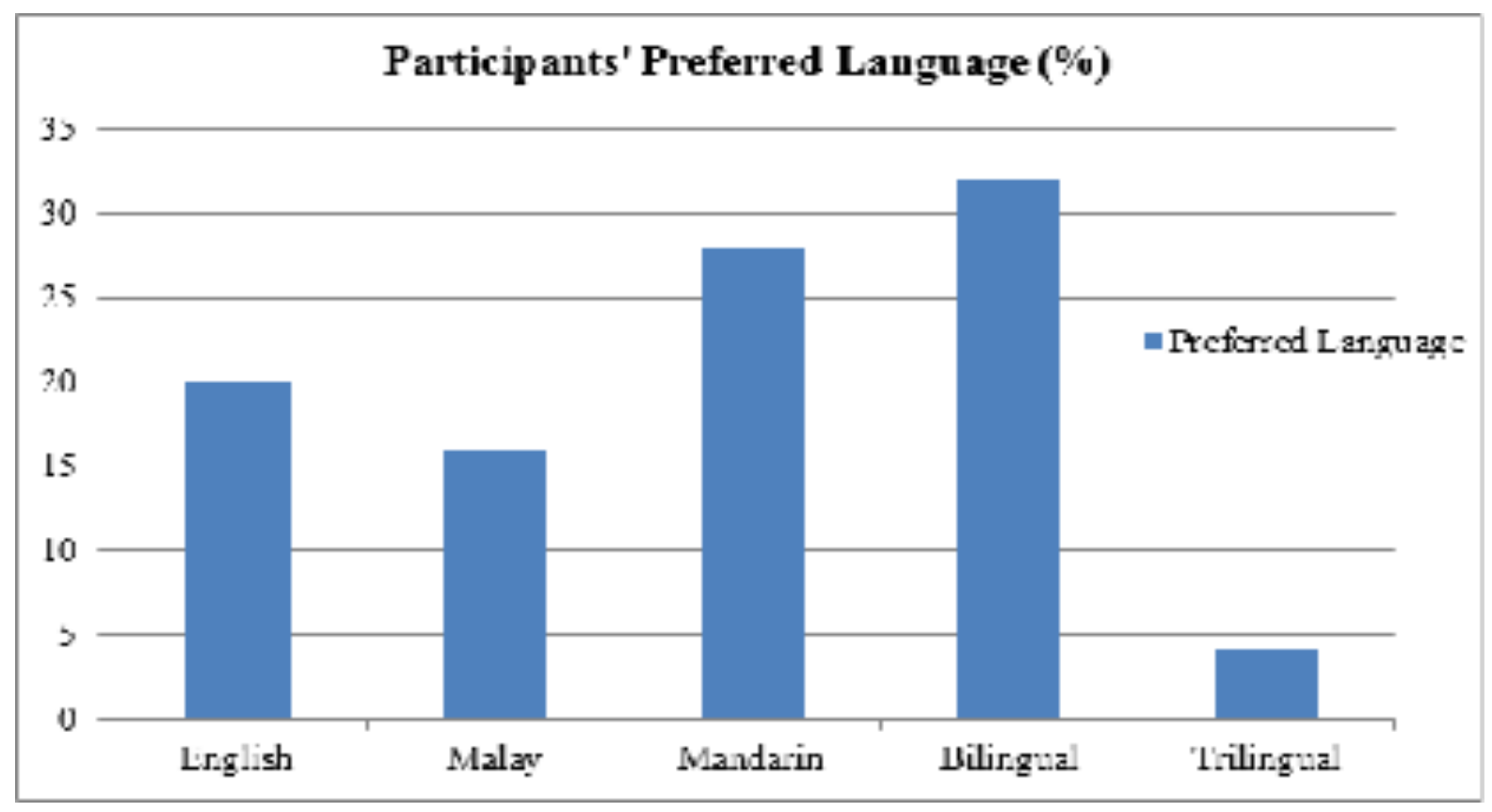

Figure 2. Participants' Preferred Language of Communication

Based on Figure 2, it is quite clear that most of the participants in the study prefer to speak in Mandarin and Malay when communicating with their peers, while English is merely viewed as a subject and after being emphasised by the teacher, they perceive English as a tool for formal interactions with the teacher, especially during lessons. This is definitely not surprising as most of the participants come from either the Chinese vernacular schools nearby, or the national type schools in the area and their first language is mainly Mandarin or Malay. As ESL 
learners, they require explicit vocabulary instruction that allows them to integrate new concepts with their existing schema (Nagy, 1988). This would then contribute to their vocabulary knowledge depth and breadth which is crucial in successful reading comprehension (Chou, 2011).

\section{Theme 2: Participants' Perceived Difficulty of English Reading Comprehension and Preferred Answering Methods}

How the learners perceived reading comprehension tasks as barriers in their language learning and how they would usually handle them were also identified.

13 participants claimed that reading comprehension was indeed a challenging task to them, identifying the lack of vocabulary as the cause of their inability to comprehend reading material. The response given by Participant 12 adequately described the struggle that learners face. He stated that, "Some of the English comprehension questions difficult and some of them is easy because the words they used on the questions." The other 12 participants claimed to be capable of attempting comprehension questions independently as they were either engaged in extensive reading in their leisure time or were doing practice exercises at home. Researchers have found that it is not always the case for ESL learners, as extensive reading beyond the classroom is hardly encouraged in schools, nor supported by the home environment (Chou, 2011; Fisher \& Frey, 2014; Glende, 2013; Hazlina Abdullah, Nik Suryani Nik Abdul Rahman \& Airil Haimi Mohd. Adnan, 2012; Naginder, 2013).

This brings the discussion to the next question on the written response handout, which required participants to identify the methods they usually engaged in when attempting reading comprehension questions. Figure 3 is a bar chart of the responses collected.

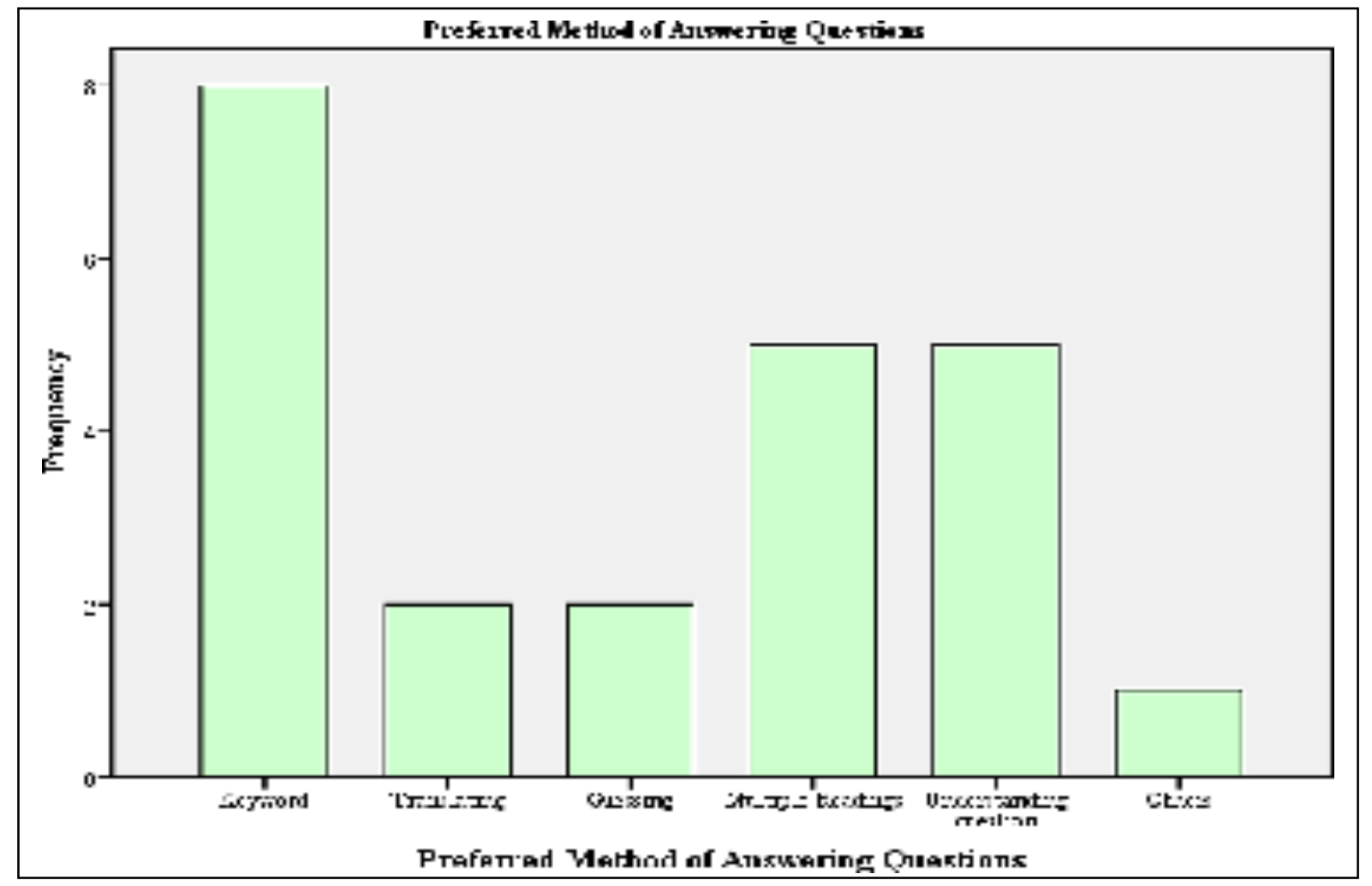

Figure 3. Participants' Preferred Methods of Answering Reading Comprehension Questions

Based on Figure 3, it can be seen that most participants preferred to use either keywords, multiple readings or attempting to understand the questions in depth when answering reading 
comprehension tasks. These methods may be preferred due to the previous exposure they have had in their primary school years. Though this method may seem to be effective and accommodate well the time and resource constraints that teachers face, Naginder (2013) and Hazlina Abdullah, Nik Suryani Nik Abdul Rahman, \& Airil Haimi Mohd. Adnan (2013) assert that the comprehension questions found in the examinations do not truly test the students' understanding of the reading text because the questions used are rote questions that have a fair chance of the answers being guessed. The preference of this method in ESL classrooms may also be widely used as it favours weaker learners but the ultimate aim should be to equip learners with language skills rather than examination answering techniques.

Even though the keywords method is emphasised, it does not necessarily mean that vocabulary instruction takes place in the classroom. On the contrary, it has been asserted by researchers time and again that it is neglected in the classrooms, resulting in the severely limited vocabulary grasp among weak learners, while proficient learners flourish by continuing to pick up vocabulary independently (Chou, 2011; Naginder, 2013; Rupley \& Nichols, 2005; Sippel, 2010; Hazlina Abdullah, Nik Suryani Nik Abdul Rahman, \& Airil Haimi Mohd. Adnan, 2013; Zhang \& Suaini bin Anual, 2008). This widening achievement gap is termed the "Matthews Effect" (Geva, Yaghoub-Zadeh, \& Schuster, 2000). This not only jeopardises the learners' academic achievements but also damages their future employment prospects (Robson, 2009).

To further highlight the importance of helping learners expand their vocabulary, the other methods mentioned by the participants such as translating, guessing, engaging in multiple readings of the passage and attempting to understand the questions require learners to be able to decode meanings of the words provided (Nelson \& Stage, 2007; Ortlieb,Verlaan \& Cheek, 2013). Thus, it should be clear that helping learners acquire vocabulary should be centralised in the classroom to ensure that they are making progress in their language learning instead of assuming that they would be able to pick up vocabulary along the way (Glende, 2013; Naginder Kaur, 2013; Normazidah Che Musa, Koo, Hazita Azman, 2012; Zhang \& Suaini Bin Anual, 2008).

\section{Theme 3: Previous Vocabulary Learning Strategies and its Effectiveness}

Researchers claim that vocabulary learning can be either incidental or intentional (Nation \& Waring, 1997; Shen, 2013). Acknowledging the significant difficulty ESL learners face in comprehending language input, educators should advocate strongly for intentional learning, otherwise known as explicit vocabulary instruction that deliberately engages learners in activities that help them develop word consciousness and vocabulary depth and breadth (Glende, 2013; Jameel Ahmad, 2011; Nagy, 1988).

The results from the written response questions agree with the notion as the participants claimed that they mostly learn vocabulary via social strategies such as through the use of social media like the YouTube, Google and peer interactions and asking teachers for clarification to acquire more vocabulary. Participant 31 claimed that she learns vocabulary, "When Miss Eunice (the teacher) or tuition class teach me." 22 of the 25 participants have also claimed that their previously mentioned vocabulary learning strategies were indeed effective in helping them in their language learning, further supporting the notion that vocabulary learning can be either incidental or intentional (Nation \& Waring, 1997; Shen, 2013). However, it is quite obvious that traditional vocabulary learning methods (extensive reading, dictionary use and spelling lists) are least favoured by the learners and they also reflect a lack of awareness of other vocabulary learning strategies, as mentioned in Azadeh Asgari \& Ghazali Bin Mustapha's (2011) study. 


\section{Theme 4: Feedback on the Use of a Vocabulary Journal and its Effectiveness}

Based on the data collected from the 25 participants, a majority (67.65\%) of the participants were of the opinion that the vocabulary journal was effective in assisting their learning of new vocabulary. This finding aligns with the findings of studies conducted by Mania Nosratinia, Zania Mohamadi Sarmadi and Hossein Shakeri (2013), McCrostie (2007) and Yung (2008), indicating that the use of vocabulary notebooks were indeed positively received by the participants of various educational and age levels.

As evidence of its effectiveness, Participant 3 stated that the vocabulary journal helped with productive use of the target word, referring to the sentence construction component of the Vocabulary Four Square Model that served as the template for each entry made in their vocabulary journals. These findings align with claims by Mezynski (1983) and Nagy (1988), asserting the need to encourage definitional as well as contextual learning by providing learners with as much information on the word as possible, allowing learners to identify the semantic relationships and relate the target word to larger 'chunks' of concepts (Rupley \& Nichols, 2005; Yung, 2008).

Only a small number (5.88\%) of the participants indicated that they did not find the vocabulary journal helpful because of the following reasons: i) they were lazy (Participant 15 and ii) it was time-consuming to complete the entries in their journals (Participant 25). These are in line with findings from Walters and Bozkurt's (2009) study, where the participants acknowledged the effectiveness but lacked the discipline to keep adding on to the notebooks independently. To overcome this, Centenario (2013), Vela and Rushidi (2016) and Walters and Bozkurt (2009) suggest including it in the formative assessment component of the subject's grading to encourage participation.

Further evidence of the effectiveness of the vocabulary journal can be seen in the number of words the participants were able to recall at the top of their heads. Of the 35 words learned during the study, 14 of the 25 participants were able to recall more than 5 words independently, while Participant 4 was able to recall as many as 11 words spontaneously, proving the point that diligence in keeping the notebook is indeed effective in the participants' vocabulary learning.

\section{Theme 5: Intention to Continue Using the Vocabulary Journal}

The researchers agree with Nelson and Stage's (2007) notion that the long term solution to help ESL learners to overcome their language learning woes is through equipping learners with word learning strategies, allowing them to become autonomous learners as word learning strategies are transferable to other areas of life (Robson, 2009). The use of the vocabulary journal kills two birds with one stone, as Yung $(2008$, p.71) claims that, "Vocabulary notebooks can be used as a tool to integrate a variety of learning strategies and make them explicit to students".

The data collected showed that $84 \%$ of the participants indicated that they intended to continue using the vocabulary journal independently to continue learning new vocabulary, while only a mere $16 \%$ of the participants who clearly stated that they had no desire to continue using the vocabulary journal on their own. These results resonate with the findings of the study conducted by Walters and Bozkurt (2009) as well as Vela and Rushidi (2016), where the learners demonstrated positive attitudes about the vocabulary notebook as the participants perceived the notebooks as their "personal dictionaries". 
Centenario (2013) also highlighted that freedom to design and include information they deem relevant is especially important among adolescents as this encourages their leadership and confidence in learning. Besides helping learners gain more vocabulary, the use of a vocabulary notebook allows learners to engage multiple word learning strategies simultaneously, which in turn promotes learner autonomy (Cuevas, Russell \& Irving, 2012; Naginder, 2012). Therefore, it is clear that the acknowledgement of learner autonomy in the vocabulary journaling method has a positive influence on the participants and this may be one factor that influenced the students to want to continue using the vocabulary journal on their own after the intervention period has ended.

\section{CONCLUSIONS}

To conclude, it is clear that the participants in the study, consisting mainly of ESL learners were previously unaware of the array of vocabulary learning strategies available at their disposal, thus hindering their language learning due to their inability to comprehend language input based on their limited vocabulary breadth and depth. Their previous vocabulary learning strategies mostly involved rote memorisation that did not encourage vocabulary depth and the lack of explicit vocabulary instruction further reinforced their misconception that English reading comprehension tasks are difficult. Based on the increase in post-test scores for both the Vocabulary Knowledge Scale and the reading comprehension tasks, it is obvious that the intervention implemented was indeed effective in helping participants increase both their vocabulary knowledge and reading comprehension abilities. Besides that, the use of a vocabulary journal guided by Frayer's Vocabulary Four Square as a template for their journal entries was positively received by the participants themselves.

Therefore, the study had answered the three research questions and it has shown that the use of a vocabulary journal is indeed an effective method to achieve the following:

a) Expose ESL learners to an effective vocabulary learning strategy that engages multiple vocabulary learning strategies to enhance vocabulary knowledge.

b) Help ESL learners to increase vocabulary knowledge and thus contributing to increased reading comprehension abilities in their language learning.

c) Encourage learner autonomy and increase learner motivation by equipping them with learning strategies that are transferable to other areas of learning.

\section{RECOMMENDATIONS}

The study had shown that the use of a vocabulary journal with the Frayer's Vocabulary Four Square model was indeed effective in helping learners acquire more vocabulary and improve reading comprehension.

Firstly, since most of the ESL learners today are native netizens, it would be logical to incorporate technology into their learning, such as encouraging the use of an electronic dictionary when looking up information about the target words as this would ensure that the sources used are reliable dictionaries rather than anonymous entries from the Internet search engines that may contain irrelevant information. This is also agreed by Cuevas, Russell \& Irving (2012), Flynn (2007) and Taveggia (2013), who have found that learners preferred reading comprehension and vocabulary learning activities that involved the use of technology in the form of using computer reading modules and electronic dictionaries in their learning.

Alternatively, teachers in school could opt to make use of the Virtual Learning Environment (VLE) Frog by setting up word quizzes and online word games using the available extensions for learners to attempt from the comfort of their homes, uploading extra reading materials that allow learners to be exposed to quality text in multiple contexts (Chung, 2012), while 
allowing learners the opportunity to engage the use of technology, as advocated by the school authorities.

Next, teachers need no reminder that the time and administrative constraints are factors that will require good time management skills. Therefore, teachers need to manage instructional time wisely to be able to cover enough academic content, while also making time to incorporate the use of the vocabulary journal in the classrooms. The introduction phase of the vocabulary journal may be quite draining, but can be eased with the following measures:

1) Putting up exemplary pieces of work in the class that serves as motivation as well as concrete examples for learners to follow.

2) Setting up a word wall in the classroom to allow for multiple repeated exposures to the target words and serve as an aesthetic piece for the typically dull looking classrooms.

3) Incorporating enrichment activities such as pop quizzes, games (Boyer, 2017; Chung, 2017; Farrukh Nazir, 2017; Uzun, 2012), word searches and peer sharing to consolidate their learning and vary instructional methods.

4) Conducting read-aloud or show and tell in class (Boyer, 2017; Farrukh Nazir, 2017).

These measures not only allow for varied instructional activities, but also allow learners to use the words and negotiate the meaning to clarify any doubts, further consolidating their learning (Taveggia, 2013).

To further encourage learner participation, it is also advised to use vocabulary journals as part of the learners' ongoing formative assessments as this may be the only way to curb their indiscipline in updating their vocabulary notebooks (Centenario, 2013; Vela \& Rushidi, 2016; Walters and Bozkurt, 2009).

Taveggia (2013) also suggests that teacher development may be needed for teachers themselves to be equipped with the skills necessary to implement the intervention in the classrooms. This finding has been highlighted in Dubiner's (2017) study with pre-service teachers that has demonstrated vocabulary acquisition and has pointed out that keeping notebooks allow for tangible documentation of one's learning. Therefore, it is clear that teacher development is also crucial in ensuring the quality of the intervention.

Lastly, Walters and Bozkurt (2009) suggest that the intervention be initiated at the beginning of the academic year to develop the habit and set the pace early so as to allow learners to quickly internalise the process and apply these strategies in other areas of learning (Glende, 2013; Centenario, 2013; Nagy, 1988; Robson, 2009), which is an area of study which currently still lacks evidential support.

Though the findings have indicated that the intervention was indeed effective, it merely serves as a preview of the potential of the use of vocabulary notebooks/vocabulary journals in helping ESL learners acquire vocabulary and subsequently improve reading comprehension. There is still much to be done to identify the vastness of the benefits that vocabulary notebooks bring. To garner stronger statistical findings and generalisable results, future studies should include a wider scope such as using a control group to show comparison and including a larger and randomised sample of participants from various educational backgrounds. This would further persuade educators and learners alike of the effectiveness of the method, benefiting teachers who have to handle classrooms of diverse learners. 


\section{References}

Abdullah, H., Rahman, N. S. N. A., \& Adnan, A. H. M. (2012). The Secondary School English Language Reading Curriculum: A Teacher's Perceptions. Online Submission. http:// files.eric.ed.gov/fulltext/ED533649.pdf

Ahmad, J. (2012). Intentional vs. incidental vocabulary learning. ELT Research Journal, 1(1), 71-79. https://www.kau.edu.sa/Files/0053226/Researches/65160_36507.pdf

Apthorp, H., Randel, B., Cherasaro, T., Clark, T., McKeown, M., \& Beck, I. (2012). Effects of a supplemental vocabulary program on word knowledge and passage comprehension. Journal of Research on Educational Effectiveness, 5(2), 160-188. http://dx.doi.org/ 10.1080/19345747.2012.660240

Asgari, A., \& Mustapha, G. B. (2011). The Type of Vocabulary Learning Strategies Used by ESL Students in University Putra Malaysia. English language teaching, 4(2), 84-90. http:// dx.doi.org/10.5539/elt.v4n2p84

Beck, I. L., McKeown, M. G., \& Kucan, L. (2013). Bringing words to life: Robust vocabulary instruction. Guilford Press.

Beck, I. L., Perfetti, C. A., \& McKeown, M. G. (1982). Effects of long-term vocabulary instruction on lexical access and reading comprehension. Journal of educational psychology, 74(4), 506.

http://psycnet.apa.org/journals/edu/74/4/506/

Benjamin, A., \& Crow, J. (2011). Receptive vs. Productive Vocabulary: Book Nook: Thinkmap Visual Thesaurus. Retrieved 27 May 2017, from https://www.visualthesaurus.com/cm/booknook/ receptive-vs-productivevocabulary/

Boyer, K. (2017). The Relationship between Vocabulary and Reading Comprehension in ThirdGrade Students Who Are English Language Learners and Reading Below Grade Level. Mdsoar.org. Retrieved 4 July 2017, from https://mdsoar.org/handle/11603/3895

Brown, D. (2008). Using a modified version of the Vocabulary Knowledge Scale to aid vocabulary development. The Language Teacher, 32(12), 15-16.

Brown, D. (2011). Using a modified version of the Vocabulary Knowledge Scale to aid vocabulary development | JALT Publications. Jalt-publications.org. Retrieved 11 April 2017, from http:// jaltpublications.org/tlt/departments/myshare/articles/628-using-modified-version- vocabulary-knowledge-scaleaid-vocabulary

Bruton, A. (2009). The vocabulary knowledge scale: A critical analysis. Language Assessment Quarterly, 6(4), 288297.http://dx.doi.org/10.1080/15434300902801909

Centenario, L. L. (2013). Vocabulary notebooks: A tool to enhance memory or a memories notebook? https://www.google.com/url? sa=t\&rct=j\&q=\&esrc=s\&source=web\&cd=1\&cad=rja\&uact=8\&ved=0ahUKEwj1pi0q_7XAhUCNo8KHT1FBc8QFggrMAA\&url=http $\% 3 \mathrm{~A} \% 2 \mathrm{~F} \% 2$ Facademicae.unavarra.es $\% 2$ Fbitstream $\% 2$ Fhandle $\% 2 F 2454 \% 2 F 9823 \% 2 F D o c u m e n t o \% 2520$ de $\% 2520$ la $\% 2520$ tesis.pdf $\% 3$ Fsequence\%3D1\&usg=A0vVaw2ht67hlRZC5_2RIIfT4Aub

Chou, P.T. M. (2011). The Effects of Vocabulary Knowledge and Background Knowledge on Reading Comprehension of Taiwanese EFL Students. Electronic Journal of Foreign Language Teaching, 8(1). https://pdfs.semanticscholar.org/ 0050/138ea2aa886e7b53b9bf7d85b6f2f3dd82c6.pdf

Chung, S. F. (2012). Based Vocabulary Instruction for English Language Learners. Reading, 12(2). http://www.readingmatrix.com/articles/september 2012/chung.pdf

Creswell, J. (2012). Educational research (4th ed.). Boston: Pearson., pp.534-576.

Cuevas, J. A., Russell, R. L., \& Irving, M. A. (2012). An examination of the effect of customized reading modules on diverse secondary students' reading comprehension and

motivation. Educational Technology Research and Development, 60(3), 445-467. http:// dx.doi.org/10.1007/s11423-012-9244-7

Curriculum Development Division. (2011). Standard Document of Primary School Curriculum: Basic Core Module of English Language for National Schools. Putrajaya: Author.

Dale, E. (1965). Vocabulary measurement: Techniques and major findings. Elementary English, 42(8), 895-948. http://www.jstor.org/stable/41385916?seq=1\#page scan tab contents

Darmi, R., \& Albion, P. (2013). English Language In Malaysian Education System: Its Existence And Implication. Research Gate. Retrieved 9 June 2017, from https://www.researchgate.net/ publication/279867616 

6(5) $173-190$

Darmi, R., \& Albion, P.(2013). English language in the Malaysian education system: Its existence and implications. In Proceedings of the 3rd Malaysian Postgraduate Conference (MPC 2013) (pp. 175-183). Education Malaysia. https://eprints.usq.edu.au/24021/

David, A. (2008). Vocabulary breadth in French L2 learners. Language Learning Journal, 36(2), 167-180. http://dx.doi.org/10.1080/09571730802389991

Dubiner, D. (2017). Using vocabulary notebooks for vocabulary acquisition and teaching. Elt Journal, 71(4), 456466. http://dx.doi.org/10.1093/elt/ccx008

English Language and its importance to Malaysia's growth. (2012). The Malaysian Times.

Kuala Lumpur, Malaysia. http://www.themalaysiantimes.com.my/english-language-and- its-importance-tomalaysia\%E2\%80\%99s-growth/

Fisher, D., \& Frey, N. (2014). Content area vocabulary learning. The Reading Teacher, 67(8), 594-599. http://dx.doi.org/10.1002/trtr.1258

Ford-Connors, E., \& Paratore, J. R. (2015). Vocabulary instruction in fifth grade and beyond: Sources of word learning and productive contexts for development. Review of Educational

Research, 85(1), 50-91. http://journals.sagepub.com/doi/abs/10.3102/0034654314540943

Gambrell, L.B., Morrow, L.M., \& Pressley, M. (2007). Best Practices in Literacy Instruction. The Guilford Press: New York.

Geva, E., Yaghoub-Zadeh, Z., \& Schuster, B. (2000). Understanding individual differences in word recognition skills of ESL children. Annals of dyslexia, 50(1), 121-154.

Glende, L. (2013). Vocabulary and word study to increase comprehension in content areas for struggling readers. http://fisherpub.sjfc.edu/cgi/viewcontent.cgi? article=1248\&context=education_ETD_masters

Hart, L. (2012). The Four-Square Method of Vocabulary Instruction. Retrieved from https:// www.brighthubeducation.com/high-school-english-lessons/25934-four-square-vocabulary- method/

Hulstijn, J. H., \& Laufer, B. (2001). Some empirical evidence for the involvement load hypothesis in vocabulary acquisition. Language learning, 51(3), 539-558. http://dx.doi.org/10.1111/0023-8333.00164

Jackson, J. R., \& Dizney, H. (1963) Intensive vocabulary training. Journal of Developmental Reading, 6, 221-229.

Jun Zhang, L., \& Bin Anual, S. (2008). The role of vocabulary in reading comprehension: The case of secondary school students learning English in Singapore. RELC Journal, 39(1), 51-76.

http:// dx.doi.org/10.1177/0033688208091140

Kaur, N. (2013). The need for autonomous vocabulary learners in the Malaysian ESL classroom. GEMA Online ${ }^{\circledR}$ Journal of Language Studies, 13(3). http://ejournal.ukm.my/gema/article/view/4216

Krashen, S. (1989). We acquire vocabulary and spelling by reading: Additional evidence for the input hypothesis. The modern language journal, 73(4), 440-464. http://dx.doi.org/10.2307/326879

Krashen, S. D. (1987). Principles and practice in second language acquisition. New York.

Kuder, S. J. (2017). Vocabulary instruction for secondary students with reading disabilities: An updated research review. Learning Disability Quarterly, 40(3), 155-164.

http:// journals.sagepub.com/doi/10.1177/0731948717690113

Kusumawati, E., \& Widiati, U. (2017). The Effects of Vocabulary Instructions on Students' Reading Comprehension across Cognitive Styles in ESP. Journal of Education and Practice, 8(2), 175-184.

http://www.iiste.org/Journals/index.php/JEP/article/view/35086

Lu, J., \& Huang, J. (2009). An empirical study of the involvement load hypothesis in incidental vocabulary acquisition in EFLlistening.

https://www.apu.ac.jp/rcaps/uploads/fckeditor/publications/polyglossia/Polyglossia V16 Lu Huang.pdf

Mezynski, K. (1983). Issues concerning the acquisition of knowledge: Effects of vocabulary training on reading comprehension. Review of educational research, 53(2), 253-279.

http://dx.doi.org/ 10.3102/00346543053002253

Mahdavi, J. N., \& Tensfeldt, L. (2013). Untangling reading comprehension strategy instruction: Assisting struggling readers in the primary grades. Preventing school failure: Alternative education for children and youth, 57(2), 77-92. http://dx.doi.org/10.1080/1045988x.2012.668576 
Mahdzir: New KSSM, KSSR curriculum from 2017. (2016). The Star OnLine. Retrieved from https://www.thestar.com.my/news/nation/2016/12/31/mahdzir-new-kssm-kssr- curriculum-from-2017/

Mahroof, S. R. (2017). Facilitating vocabulary learning in teaching English as a second Language in Sri Lanka: A comparative study. http://ir.lib.seu.ac.lk/handle/123456789/2160

Marzano, R. J. (2009). The art and science of teaching: Six steps to better vocabulary instruction. Educational leadership, 67(1), 83-84. http://sites.uci.edu/bsemdpedagogyposts/ files/2014/02/Six-Steps-to-BetterVocabulary-Instruction.pdf

McCrostie, J. (2007). Examining learner vocabulary notebooks. ELT journal, 61(3), 246-255. http:// dx.doi.org/10.1093/elt/ccm032

McKeown, M. G., \& Beck, I. L. (2011). Making vocabulary interventions engaging and effective. Handbook of reading interventions, 138-168.

Ministry to study preparedness to implement compulsory pass in English for SPM. (2016). The Sun Daily. http://www.thesundaily.my/news/1812842

Musa, N. C., Lie, K. Y., \& Azman, H. (2012). Exploring English language learning and teaching in Malaysia. GEMA Online ${ }^{\circledR}$ Journal of Language Studies, 12(1). http://ejournal.ukm.my/gema/article/view/20

Nagy, W. E. (1988). Teaching vocabulary to improve reading comprehension. National Council of Teachers of English, 1111 Kenyon Rd., Urbana, IL 61801 (Stock No. 52384-015, \$4.95 member, \$7.50 nonmember--ISBN-08141-5238-4); International Reading Association, PO Box 8139, 800 Barksdale Rd., Newark, DE 19714-8139 (No. 151, \$4.95 member, \$7.50 non- member--ISBN-0-87207-151-0). http://files.eric.ed.gov/fulltext/ED298471.pdf

Nagy, W., \& Townsend, D. (2012). Words as tools: Learning academic vocabulary as language acquisition. Reading Research Quarterly, 47(1), 91-108. http://dx.doi.org/10.1002/rrq.011

Nation, I. (2006). How large a vocabulary is needed for reading and listening?. Canadian Modern Language Review, 63(1), 59-82. http://dx.doi.org/10.3138/cmlr.63.1.59

Nazir, F. (2017). A COLLECTIVE CASE STUDY ON VOCABULARY INSTRUCTION IN FIFTH GRADE CLASSROOMS. https://scholarworks.umt.edu/etd/10947/

Nelson, J. R., \& Stage, S. A. (2007). Fostering the development of vocabulary knowledge and reading comprehension though contextually-based multiple meaning vocabulary instruction. Education and treatment of children, 30(1), 1-22. http://digitalcommons.unl.edu/cgi/viewcontent.cgi?article=1028\&context=specedfacpub

Nosratinia, M., Mohammadi Sarmadi, Z., \& Shakeri, H. (2013). The Comparative Effect of Keeping a Vocabulary Notebook with Definitions and a Vocabulary Notebook with Pictures on Extrovert and Introvert EFL Learners Vocabulary Retention. http://www.ijllalw.org/ finalversion4215.pdf

Ortlieb, E., Verlaan, W., \& Cheek, E. H. (2013). Vocabulary/comprehension-based models of reading clinics. In Advanced Literacy Practices (pp. 117-136). Emerald Group Publishing Limited. http://dx.doi.org/10.1108/S20480458(2013)0000002009

Peters, C. (1974). A Comparison between the Frayer Model of Concept Attainment and the Textbook Approach to Concept Attainment. Technical Report No. 290.http://www.jstor.org/stable/ 747186

Pusat Perkembangan Kurikulum Kementerian Pendidikan Malaysia. (2001). Sukatan pelajaran kurikulum bersepadu sekolah menengah Bahasa Inggeris, pp.1-13. Retrieved from https:// www.malaysian-ghostresearch.org/wp-content/uploads/2017/03/sp_bi_kbsm.pdf

Pusat Perkembangan Kurikulum Kementerian Pendidikan Malaysia. (2016). Sukatan Pelajaran Kurikulum Standard Sekolah Menengah Bahasa Inggeris pp. 1-104.

Robertson, F. (2015). Reading, writing and the importance of vocabulary. Headteacher Update, 2015(3), 28-30. http://www.headteacher-update.com/best-practice-article/reading- writing-and-the-importance-ofvocabulary/82451

Robson, J. M. (2009). A study examining the impact of vocabulary instruction on the vocabulary growth and acquisition of adults enrolled in a community college developmental reading course. Florida Atlantic University.http://gradworks.umi.com/33/88/3388750.html

Rupley, W. H., \& Nichols, W.D. (2005). Vocabulary instruction for the struggling reader. Reading \& Writing Quarterly, 21(3), 239-260. http://dx.doi.org/10.1080/10573560590949368

Sarbazi, M. R. (2014). Involvement load hypothesis: Recalling unfamiliar words meaning by adults across genders. Procedia-Social and Behavioral Sciences, 98, 1686-1692. http://dx.doi.org/ 10.1016/j.sbspro.2014.03.594 
Schmitt, N. (1997). Vocabulary learning strategies. Vocabulary: Description, acquisition and pedagogy, 199227.Cambridge: Cambridge University Press.

Schutz, R. (2005). Stephen Krashen's Theory of Second Language Acquisition. Retrieved 14 July 2017, from https://apps.esc1.net/ProfessionalDevelopment/uploads/WKDocs/ 58121/2.\%20Stephen\%20Krashen.pdf

Shen, Z. (2013). The effects of vocabulary knowledge and dictionary use on EFL reading performance. English Language Teaching, 6(6), 77. http://dx.doi.org/10.5539/elt.v6n6p77

Sippel, S. (2010). Effective explicit methods of vocabulary instruction (Doctoral dissertation, Concordia University).

Sulaiman, T., Ayub, A. F. M., \& Sulaiman, S. (2015). curriculum change in English language curriculum advocates higher order thinking skills and standards-based assessments in Malaysian primary schools. Mediterranean Journal of Social Sciences, 6(2), 494.http:// dx.doi.org/10.5901/mjss.2015.v6n2p494

Taveggia, D. E. (2013). Adapting a vocabulary notebook strategy to the needs of community college English language learners (Doctoral dissertation, University of Kansas). https://

kuscholarworks.ku.edu/bitstream/handle/1808/15096/ Taveggia_ku_0099D_12690_DATA_1.pdf;sequence=1

Thornbury, S. (2006). How to teach vocabulary. Pearson Education India.

Townsend, D., \& Collins, P. (2009). Academic vocabulary and middle school English learners: An intervention study. Reading and Writing, 22(9), 993-1019.

Uzun, L. (2013). Promoting vocabulary learning through vocabulary notebooks: Teaching and learning strategies and gender. Journal of Academic Language and Learning, 7(1), A1-A13.

https://www.researchgate.net/publication/276934728_Promoting_vocabulary_learning_through_vocabulary_not ebooks_Teaching_and_learning_strategies_and_gender

Vela, V., \& Rushidi, J. (2016). The Effect of Keeping Vocabulary Notebooks on Vocabulary Acquisition and Learner Autonomy. Procedia - Social And Behavioral Sciences, 232, 201-208.

http://dx.doi.org/10.1016/j.sbspro.2016.10.046

Walters, J., \& Bozkurt, N. (2009). The effect of keeping vocabulary notebooks on vocabulary acquisition. Language Teaching Research, 13(4), 403-423.http://dx.doi.org/10.1177/1362168809341509

Wang, Y. (2013). Incidental vocabulary learning through extensive reading: a case of lower-level EFL Taiwanese learners. The Journal of Asia TEFL, 10(3), 59-80.

Waring, R. (2002). Scales of vocabulary knowledge in second language vocabulary assessment. Appeared in Kiyo: The Occasional Papers of Notre Dame Seishin University, Japan.

Yung, W. K. (2008). The effectiveness of vocabulary notebooks on vocabulary acquisition of a form- two Chineseas-the-medium-of-instruction (CMI) class. 香香港大大學學位論文文.

Zhang, L., \& Suaini Bin Anual. (2008). The Role of Vocabulary in Reading Comprehension: The Case of Secondary School Students Learning English in Singapore. RELC Journal, 39(1), 51-76.

http://dx.doi.org/10.1177/0033688208091140 